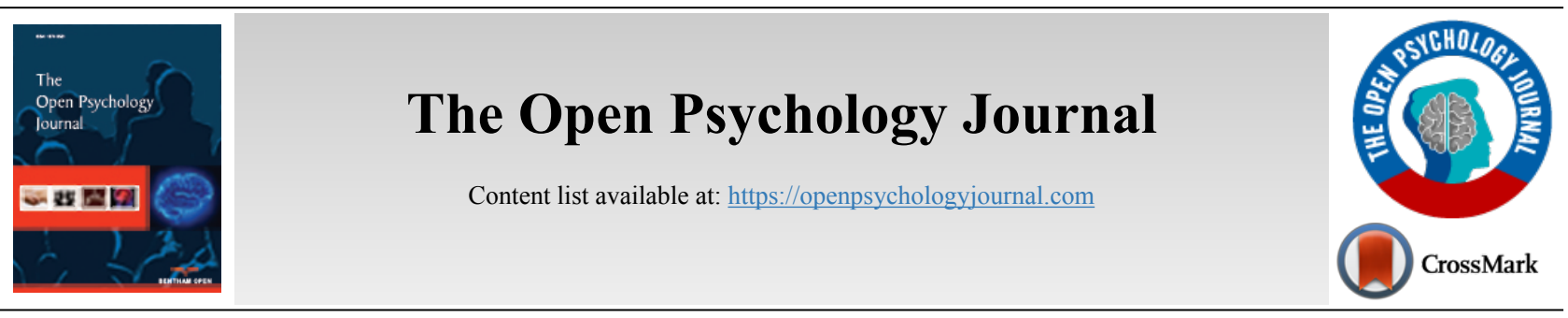

RESEARCH ARTICLE

\title{
Effect of Students' Emotions on their Positive Psychology: A Study of Higher Education Institutions
}

\author{
Rajat Grover ${ }^{1}$, Arun Aggarwal ${ }^{1, *}$ and Amit Mittal ${ }^{1}$ \\ ${ }^{\text {l}}$ Chitkara Business School, Chitkara University, Punjab, India
}

\begin{abstract}
:
Background:

In the higher education sector, anticipating and fostering positive emotions manifest the view of positive psychology is considered as an essential practice.

Aims:

The present study aims to identify and statistically validate the different types of students' emotional indicators.

Methods:

A survey was carried out in three cities, namely Mumbai, Pune, and Chandigarh of India. A total of 566 valid survey responses were analyzed using exploratory factor analysis and confirmatory factor analysis. The results of the confirmatory factor analysis demonstrated six sets of emotions measurement indicators, namely anger, disgust, happiness, positive emotions, sadness, and fear for measuring students' emotions.

Results:

Further, the results of path analysis showed that happiness, positive emotions, sadness, disgust, and fear had positive effect on positive psychology.

Conclusion:

Overall, this study highlights the imperativeness of students' emotional measurement, and the study results provide a deep understanding of both positive and negative emotions measurement, which may further support the overall development of the students, especially in higher education institutions.
\end{abstract}

Keywords: Emotion, Perceived control, Sadness, Control value theory, Happiness, Structural equation modeling.

\begin{tabular}{|l|l|l|r}
\hline Article History & Received: April 24, 2020 & Revised: June 03, 2020 & Accepted: August 07, 2020
\end{tabular}

\section{INTRODUCTION}

In cognitive science, the emotions are considered as powerful predictors of an individual's behavior $[1,2]$. In the literature, emotions are defined differently by different authors. Oatley, Keltner and Jenkins [3] defined emotions as communication between people and people, which comprises behavior, physiological variations, and subjective experience [4] reported emotions as the mental condition of readiness rooted by one's thoughts and external events. However, various factors affect emotions such as perception, environmental factors, physical health, self-awareness, and stress, etc [5]. On

\footnotetext{
* Address correspondence to this author at the Chitkara Business School,
} Chitkara University, Punjab, India; E-mail: arunaggarwal.mba@gmail.com the one hand, positive emotions consist of happiness, joy, and love, facilitate in relieving stress, avoid danger, and live a healthy life [6]. On the other hand, negative emotions, which include distress and anxiety, negativity, self-directed appraisals, and ruminative tendencies, not merely affect psychological health but on physical health as well [7], which further also affects actions and decision-making [8].

The prior contributions claimed that the presence of depressive episodes is highest among young adults (aged between 18-25 years) [9] and young adulthood, which decreases the quality of life as well as social functioning later in life [10]. Considering these factors, researchers tried to explore the role of emotions in the learning context [11]. According to Derick et al. [12], in the academic surroundings, 
there is high diversity in positive and negative emotions among students. Emotions drive attention, which leads to learning and memory [13]. Likewise, emotions influence students' performance through their cognitive resources, motivational practice, and problem-solving ways [14]. According to Phan et al [6], positive emotions facilitate the students in adjustments, making friends, and engaging in proactive social associations with others. Park et al. [15] stressed that the negative emotions, namely boredom, and hopelessness, hinder the learning, whereas positive emotions, namely enjoyment, and happiness, contribute to knowledge. Therefore, the "positive psychology" of an individual plays a vital role in how an individual evaluates his/her circumstance. Positive Psychology can be defined as "the scientific study of optimal functioning" [16]. Hence, positive psychology seeks to identify various skills and strengths of individuals that help them to thrive for the best. In the current research, authors assume positive psychology as a distinct way of inspecting the individual's condition rather than seeing it as a separate entity. Positive psychology works on the assumption that humans will thrive for best, given the right amount of skills, social context, and strengths [17]. Hence, positive psychology is a complex and heterogeneous field, consisting of interventions for promoting resilience, positive emotions, engagement, meaning, curiosity, social connectedness, and many other things [18].

The arguments mentioned above highlight the role of positive emotions among students. In this context, previous studies have made valuable efforts to explore the role of positive emotions. The majority of these studies are conducted in the developed country context. Moreover, scientific, academic literature lacks a survey that can provide a holistic understanding of the emotional indicators of students. Therefore, this study aims to bridge this research mentioned above void by identifying and statistically validating the emotional indicators of students in the Indian higher education sector context, which is considered to be a crucial social sector in the country [19].

This paper proceeds as follows: Section 2 discusses the related prior contributions. The research methods are demonstrated in Section 3. Section 4 reports the analysis and results. Section 5 discusses the conclusions and implications of the study.

\section{HYPOTHESIS DEVELOPMENT}

Nowadays, in the scientific literature, the role of emotions in the education sector has attained significant attention among academicians and researchers. In different academic settings, students experience mixed sentiments that manifest their behavior [20, 21]. Emotional processes shape learning, thoughts, and behavior, indicating that emotional cognition can be related to students' attitudes towards learning and entrepreneurial activities [22]. The most inclusive theoretical framework demonstrating the imperativeness of emotions in education is the control-value theory of achievement emotions $[17,23]$. The variations in emotions are crucial predictors of the emotional conflicts that describe depression and unease [24]. The unexpected events demand explanations, and emotions are perceived to be experienced [25]. The emotional ecology concept confronts the traditional polarization of reason and feeling [26]. Researchers reported that persons with negative emotions usually engage in frequent negative thinking and less engaged in positive thinking [21, 27].

In addition to this, the literature claimed that anxiety decreases the attention span of students. Thus their emotional condition can have a significant effect on how they perceived the particular information [28]. Baker et al. [29] found that frustration is the common negative emotion during learning and can lead to disengagement with the learning material. Likewise, Taub et al. [30] reported frustration as a significant predictor of cognitive learning. On the other hand, when students achieve particular goals and found solutions to problems, they experience positive feelings such as happiness [27, 31, 32].

According to Zembylas [33], emotions are important factors that affect the relationships between teachers and students and social structures in the educational sector. Mainhard et al. [34] manifested that how a teacher interpersonally associates with their students mainly depends on the emotions of the student. Few researchers have conducted a comparison between the possibilities to consider the diverse emotion strategies such as expressive suppression versus cognitive reappraisal $[10,35,36]$. Peterson, Brown and Jun [37] reported that commonly the favorable emotions are endorsed more strongly than adverse emotions but are weaker at the start of the examination. Kashdan and Ciarrochi [17] classified emotions as per valence, the extent of activation, and object focus. Accordingly, valence reports to negative and positive, activation reports to activating and deactivating, and object reports to output prospective and output retrospective.

Further, Pekrun et al. [38] found a significant positive correlation between perceived control and positive activating emotions and negative relationship between perceived control and negative activating emotions. Lopez and Denny [7] investigated the role of emotions in goal-oriented behavior by formulating a framework for evaluating the emotional goal structure. Further, Pekrun et al. [39] reported a linkage between students' emotions and their academic achievements. On the other hand, during the exam, students feel relief, confident, hopeful, or upset based on how they supposed their progressive performance. Besides, post-exam, positive feelings are more strongly increased than negative $[27,40]$.

Linnenbrink and Pintrich [41] reported that unpleasant emotions could then further affect students' goals. LinnenbrinkGarcia and Pekrun [42] elaborated that how and why students' emotions appear and how their emotions shape their involvement and accomplishments and how they can optimize the emotional resources for improving their participation and achievements. However, individuals with emotional conflicts are more likely to reduce their emotional experience than individuals with controlled emotions [32]. Cardon et al [43]. discussed the individual and social notion in emotions and highlighted the importance of emotion management. Further, Wharton et al. [44] highlighted that the management of emotion needs energy exertion, and emotional dissonance results in unfavorable psychosomatic outcomes. 
Based on literature support, the following six research hypotheses were proposed:

H1: Happiness shall positively impact positive psychology.

H2: Positive emotions shall positively impact positive psychology.

H3: Sadness shall negatively impact positive psychology.

H4: Anger shall negatively impact positive psychology.

H5: Disgust shall negatively impact positive psychology.

H6: Fear shall negatively impact positive psychology.

\section{RESEARCH METHODOLOGY}

Further, a thorough literature review and in-depth discussions with psychology experts were taken as bases to develop the survey questionnaire. The questionnaire was forwarded to six experts. Based on the expert's recommendations, few items were eliminated, and few items were rewritten to enhance the clarity of the questions. The survey responses were recorded using a 5-point Likert scale. In this line, a total of 1500 questionnaires were distributed to the students in universities and colleges studying within three Indian cities, namely Mumbai, Pune, and Chandigarh. However, only 566 valid responses after eliminating the halffilled questionnaire were received in return. This shows the $37.73 \%$ survey response rate. Thus, the $37.73 \%$ survey response rate can be considered as sufficient for the analysis.

Table 1 shows the respondent's characteristics. The table shows that the majority of respondents belong to the male category $(61.1 \%)$ followed by females $(39.9 \%)$. As concerned to the age, majority of respondents belong to the age group between 20 and 25 years $(80 \%)$ followed by less than 20 (11.75), between 26 and $30(6.4 \%)$, between 31 and $35(1.6 \%)$, and more than 35 years $(0.2 \%)$. From the educational point-ofview, $67.3 \%$ of respondents were post-graduate, $26.7 \%$ were graduate-undergoing, $5.8 \%$ were graduates, and $0.2 \%$ were doctoral. Lastly, $6.4 \%$ of respondents were working somewhere, and the remaining $96.6 \%$ of respondents were nonworking.

\section{RESULTS AND DISCUSSION}

\subsection{Sample Adequacy}

The collected data were further analyzed using appropriate statistical tools. In this context, as a first step, the sample adequacy was evaluated considering Kaiser-Meyer-Olkin (KMO) and item's commonalities. The analysis achieved a $\mathrm{KMO}$ value of 0.828 , which is above the minimum required threshold. In the same vein, In addition, the analysis confirmed Chi-Square $\left(\chi^{2}\right)=7739.321$, degree of freedom $(\mathrm{DF})=406$, and significance value (Sig.) $=0.000$. Similarly, the item's communalities were evaluated, and 0.5 was considered as the minimum threshold [45]. Accordingly, FE2 was eliminated due to low communality. The other communalities were meeting the minimum suggested thresholds, which provide the support for conducting EFA [45].

\subsection{Exploratory Factor Analysis}

As a next step, the exploratory factor analysis (EFA) was applied, and an eigenvalue greater than one was considered for factors extraction [46]. EFA extracted six relevant factors cumulatively, explaining the $65.45 \%$ variance (Table 2). After the in-depth evaluation of the statements under each factor, the factors were labeled as anger, disgust, happiness, positive emotions, sadness, and fear, respectively. The first extracted, anger, has an eigenvalue of 4.481 , and it explains $15.45 \%$ variance. The second factor, disgust, has an eigenvalue of 3.791 , and it explains $13.07 \%$. The third factor, happiness, has an eigenvalue of 3.314 , and it demonstrates a $10.80 \%$ variance. Subsequently, the fourth factor, emotions, has an eigenvalue of 2.876 , and it explains $9.91 \%$ variance. The fifth factor, sadness, explains $8.93 \%$ variance with eigenvalue 2.592 . The last extracted factor, fear, explains a $7.26 \%$ variance with eigenvalue 2.106 (Table 2).

Table 2 reported items loading under their related construct. The literature suggested that loading for each item should be above $0.5[47,48]$. For anger, the factor loadings were between 0.762 and 0.888 . For disgust, factor loadings were between 0.0 .735 and 0.862 , and between 0.764 and 0.836 for happiness. The factor loadings were between 0.751 and 0.843 for positive emotions, and between 0.727 and 0.811 for sadness. Lastly, for the fear, the factor loadings were between 0.713 and 0.854 . This is an indication that all the item's factor loadings are statistically acceptable as these were greater than 0.5 . Further, the descriptive and reliability analysis for each extracted factor was performed. Further, to ensure the stability and consistency of the results, Cronbach's alpha was taken into account. Kaiser [49] suggested 0.5 as a minimum alpha threshold. Table 2 shows that the Cronbach alpha value for each construct is above 0.5 .

\subsection{Confirmatory Factor Analysis}

Subsequently, confirmatory factor analysis (CFA) was used to validate the six extracted factors. CFA is a tool that is very important and has been used in previous studies very effectively [50 - 52]. Fig. (1) reports to the CFA model. The CFA model was used to assess the convergent and discriminant validities. Accordingly, the CMIN/DF, GFI, NFI, TLI, CFI, and RMSEA values were used as benchmarks to evaluate the potency of model fit [45]. The researcher suggested that CMIN/DF should be below 3. The GFI, IFI, TLI, and CFI should be above 0.90 , and RMSEA should be below 0.08 . The results obtained CMIN/DF equal to 2.32, which is below the recommended value of 3. Likewise, GFI, IFI, TLI, and CFI are above 0.90 , and RMSEA is below 0.08. All these values indicate a good model fit [53, 54].

Table 3 summarizes to the of CFA model validation. Table 4 shows that analysis obtained $\mathrm{CR}=0.843, \mathrm{AVE}=0.519$, and MSV $=0.029$ for the "emotion". For the "happiness", the analysis obtained $\mathrm{CR}=0.856, \mathrm{AVE}=0.545$, and $\mathrm{MSV}=$ 0.021 . Further, "disgust" has $\mathrm{CR}=0.876, \mathrm{AVE}=0.587$, and $\mathrm{MSV}=0.045$, and factor "sadness" has $\mathrm{CR}=0.834$, AVE $=$ 0.503 , and MSV $=0.029$. Factor, "fear" has $\mathrm{CR}=0.814$, AVE $=0.525$, and $\mathrm{MSV}=0.035$, and lastly, "anger" has $\mathrm{CR}=0.903$, $\mathrm{AVE}=0.653$, and $\mathrm{MSV}=0.045$. Likewise, the square root of the AVE for the all six constructs is above than their interconstruct correlation. 


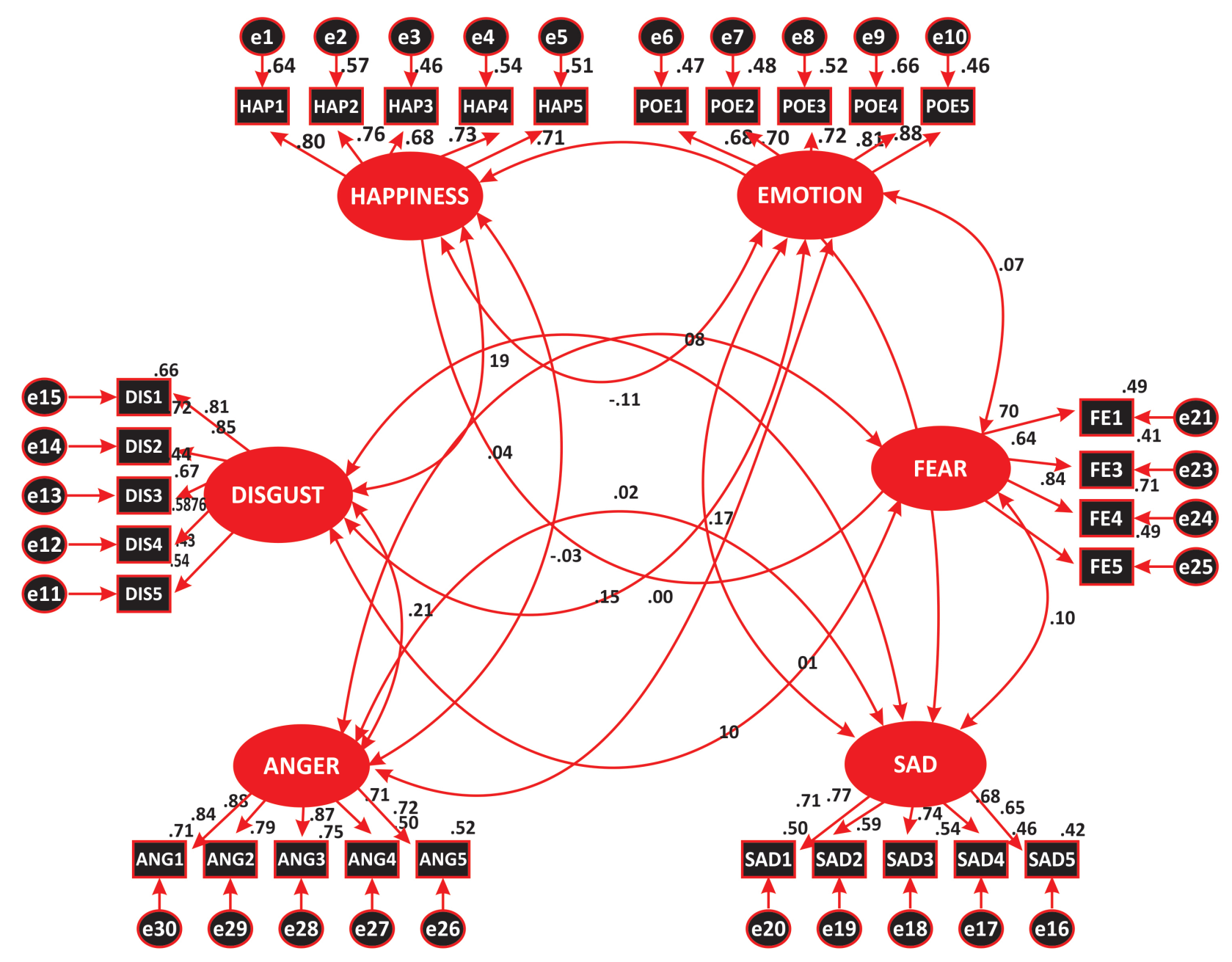

Fig. (1). Confirmatory Factor Model.

Table 1. Characteristics of Respondents.

\begin{tabular}{|c|c|c|c|}
\hline No. & Type & Number & \multicolumn{2}{|c|}{ Percentage } \\
\hline $\mathbf{1}$ & Gender & 346 & 61.1 \\
\hline & Male & 220 & 39.9 \\
\hline & Female & \multicolumn{2}{|c|}{} \\
\hline $\mathbf{2}$ & Age (Years) & 66 & 11.7 \\
\hline & Less than 20 & 453 & 80.0 \\
\hline & Between 20-25 & 36 & 6.4 \\
\hline & Between 26-30 & 9 & 1.6 \\
\hline
\end{tabular}




\begin{tabular}{|c|c|c|c|}
\hline & More than 35 & 2 & 0.2 \\
\hline \multirow[t]{5}{*}{3} & Education & & \\
\hline & Undergraduates (pursuing) & 151 & 26.7 \\
\hline & Undergraduates & 33 & 5.8 \\
\hline & Post-Graduates & 381 & 67.3 \\
\hline & Research Scholars & 1 & 0.2 \\
\hline \multirow[t]{3}{*}{4} & Working & & \\
\hline & No & 530 & 96.6 \\
\hline & Yes & 36 & 6.4 \\
\hline
\end{tabular}

Source: Author's Compilation.

Table 2. Rotated Component Matrix.

\begin{tabular}{|c|c|c|c|c|c|c|}
\hline \multirow[b]{2}{*}{ Items } & \multicolumn{6}{|c|}{ Factor } \\
\hline & Anger & Disgust & Happiness & $\begin{array}{l}\text { Positive } \\
\mid \text { Emotions }\end{array}$ & Sadness & Fear \\
\hline My friends say that I argue a lot & 0.888 & & & & & \\
\hline I may hit someone if he or she provokes me & 0.877 & & & & & \\
\hline I have threatened people I know & 0.870 & & & & & \\
\hline I wonder what people want when they are nice to me & 0.807 & & & & & \\
\hline I have become so mad I have broken things & 0.762 & & & & & \\
\hline You see someone accidentally stick a fishing hook through his finger & & 0.862 & & & & \\
\hline You see someone put ketchup on vanilla ice cream, and eat it & & 0.828 & & & & \\
\hline You are about to drink a glass of milk when you smell that it is spoiled & & 0.815 & & & & \\
\hline You are walking barefoot on concrete, and you step on an earthworm & & 0.800 & & & & \\
\hline $\begin{array}{l}\text { You take a sip of soda, and then realize that you drank from the glass that an } \\
\text { acquaintance of yours had been drinking from }\end{array}$ & & 0.735 & & & & \\
\hline In general, I consider myself Happy & & & 0.836 & & & \\
\hline $\begin{array}{l}\text { Compared to most of my peers, I consider } \\
\text { myself Happy }\end{array}$ & & & 0.806 & & & \\
\hline I want to be happy and flourishing & & & 0.780 & & & \\
\hline $\begin{array}{l}\text { Some people are generally not very happy. Although they are not depressed, they } \\
\text { never seem as happy as they might be }\end{array}$ & & & 0.774 & & & \\
\hline $\begin{array}{c}\text { Some people are generally very happy. They enjoy life regardless of what is going } \\
\text { on, getting the most out of everything }\end{array}$ & & & 0.764 & & & \\
\hline $\begin{array}{l}\text { When I'm faced with a stressful situation, I make myself think about it in a way } \\
\text { that helps me stay calm }\end{array}$ & & & & 0.843 & & \\
\hline When I am feeling positive emotions, I am careful not to express them & & & & 0.777 & & \\
\hline $\begin{array}{l}\text { When I want to feel less negative emotion (such as sadness or anger), I change } \\
\text { what I'm thinking about }\end{array}$ & & & & 0.769 & & \\
\hline I control my emotions by changing the way I think about the situation I'm in & & & & 0.752 & & \\
\hline $\begin{array}{c}\text { When I want to feel more positive emotion (such as joy or amusement), I change } \\
\text { what I'm thinking about }\end{array}$ & & & & 0.751 & & \\
\hline Compared to most of my peers, I consider myself Sadness & & & & & 0.811 & \\
\hline Small things and situations can easily make me Sadness & & & & & 0.795 & \\
\hline In general, I consider myself Sadness & & & & & 0.764 & \\
\hline I know how to handle people / situations that makes me feel Sadness & & & & & 0.758 & \\
\hline Past experience always have make me feel Sadness & & & & & 0.727 & \\
\hline Having lots of joy and fun causes bad things to happen. & & & & & & 0.854 \\
\hline Excessive joy has some bad consequences & & & & & & 0.794 \\
\hline I prefer not to be too joyful, because usually joy is followed by sadness. & & & & & & 0.788 \\
\hline Disasters often follow good fortune" & & & & & & 0.713 \\
\hline Eigen value & 4.48 & 3.79 & 3.31 & 2.87 & 2.59 & 2.10 \\
\hline$\%$ Variance & 15.45 & 13.07 & 10.80 & 9.91 & 8.93 & 7.26 \\
\hline Cumulative variance & 15.45 & 28.52 & 39.32 & 49.23 & 58.16 & 65.42 \\
\hline Cronbach's alpha & 0.899 & 0.874 & 0.854 & 0.841 & 0.830 & 0.809 \\
\hline
\end{tabular}


Table 3. Validation of the measurement model.

\begin{tabular}{|l|l|l|l|l|l|l|l|l|l|}
\hline Factor & CR & AVE & MSV & $\mathbf{1}$ & $\mathbf{2}$ & $\mathbf{3}$ & $\mathbf{4}$ & $\mathbf{5}$ & $\mathbf{6}$ \\
\hline Emotion & 0.843 & 0.519 & 0.029 & $\mathbf{0 . 7 2 1}$ & & & & \\
\hline Happiness & 0.856 & 0.545 & 0.021 & -0.110 & $\mathbf{0 . 7 3 8}$ & & & & \\
\hline Disgust & 0.876 & 0.587 & 0.045 & -0.001 & 0.011 & $\mathbf{0 . 7 6 6}$ & & & \\
\hline Sadness & 0.834 & 0.503 & 0.029 & 0.169 & -0.107 & 0.034 & $\mathbf{0 . 7 0 9}$ & & \\
\hline Fear & 0.814 & 0.525 & 0.035 & 0.068 & 0.145 & 0.185 & 0.099 & $\mathbf{0 . 7 2 5}$ & \\
\hline Anger & 0.903 & 0.653 & 0.045 & 0.008 & -0.027 & 0.213 & 0.015 & 0.186 & $\mathbf{0 . 8 0 8}$ \\
\hline
\end{tabular}

Source: Author's Compilation.

Table 4 reports the standardized estimate, S.E., C.R., significance level, and R square of each item. In this line, the standardized estimates are between 0.803 and 0.681 for the "happiness", 0.679 and 0.813 for "happiness", 0.667 and 0.848 for "disgust", 0.469 and 0.768 for "sadness", 0.640 and 0.842 for "fear", and between 708 and 0.888 for the "anger".

\section{Table 4. Standardizing Regression Weights.}

\begin{tabular}{|c|c|c|c|c|c|c|c|}
\hline & & & Estimate & S.E. & C.R. & $\mathbf{P}$ & $\mathbf{R}^{2}$ \\
\hline HAP1 & $<---$ & Happiness & 0.803 & & & & 0.645 \\
\hline HAP2 & $<--$ & Happiness & 0.756 & .051 & 18.132 & $* * *$ & 0.571 \\
\hline HAP3 & $<---$ & Happiness & 0.681 & .056 & 16.145 & $* * *$ & 0.463 \\
\hline HAP4 & $<--$ & Happiness & 0.732 & .054 & 17.510 & $* * *$ & 0.536 \\
\hline HAP5 & $<---$ & Happiness & 0.712 & .062 & 16.983 & $* * *$ & 0.507 \\
\hline POE1 & $\mid<--$ & Emotion & 0.684 & & & & 0.467 \\
\hline POE2 & $<---$ & Emotion & 0.695 & .080 & 14.281 & $* * *$ & 0.483 \\
\hline POE3 & $<<--$ & Emotion & 0.723 & .081 & 14.752 & $* * *$ & 0.522 \\
\hline POE4 & $<--$ & Emotion & 0.813 & .085 & 16.073 & $* * *$ & 0.662 \\
\hline POE5 & $<--$ & Emotion & 0.679 & .088 & 13.991 & $* * *$ & 0.461 \\
\hline DIS5 & $<--$ & Disgust & 0.734 & & & & 0.538 \\
\hline DIS4 & $\mid<--$ & Disgust & 0.759 & .059 & 17.273 & $* * *$ & 0.576 \\
\hline DIS3 & $<<--$ & Disgust & 0.667 & .051 & 15.152 & $* * *$ & 0.445 \\
\hline DIS2 & $<<--$ & Disgust & 0.848 & .056 & 19.179 & $* * *$ & 0.719 \\
\hline DIS1 & $<<--$ & Disgust & 0.809 & .064 & 18.404 & $* * *$ & 0.655 \\
\hline SADNESS5 & $<<--$ & Sadness & 0.649 & & & & 0.421 \\
\hline SADNESS4 & $<<--$ & Sadness & 0.679 & .074 & 13.222 & $* * *$ & 0.462 \\
\hline SADNESS3 & $<---$ & Sadness & 0.737 & .068 & 14.036 & $* * *$ & 0.543 \\
\hline SADNESS2 & $<---$ & Sadness & 0.768 & .069 & 14.428 & $* * *$ & 0.590 \\
\hline SADNESS1 & $<---$ & Sadness & 0.706 & .072 & 13.609 & $* * *$ & 0.498 \\
\hline FE1 & $<<--$ & Fear & 0.703 & & & & 0.494 \\
\hline FE3 & $<<--$ & Fear & 0.640 & .060 & 13.351 & $* * *$ & 0.409 \\
\hline FE4 & $<<--$ & Fear & 0.842 & .068 & 15.998 & $* * *$ & 0.709 \\
\hline FE5 & $\mid<---$ & Fear & 0.699 & .068 & 14.434 & $* * *$ & 0.489 \\
\hline ANG5 & $<---$ & Anger & 0.721 & & & & 0.520 \\
\hline ANG4 & $<<--$ & Anger & 0.708 & .061 & 16.296 & $* * *$ & 0.501 \\
\hline ANG3 & $<<--$ & Anger & 0.867 & .054 & 19.986 & $* * *$ & 0.752 \\
\hline ANG2 & $<---$ & Anger & 0.888 & .055 & 20.418 & $* * *$ & 0.788 \\
\hline ANG1 & $<<--$ & Anger & 0.840 & .061 & 19.384 & $* * *$ & 0.706 \\
\hline
\end{tabular}

S.E. $=$ Standard error; C.R. $=$ Composite reliability.

Table 5. Model Fit Indices.

\begin{tabular}{|c|c|c|}
\hline Indices & $\begin{array}{c}\text { Obtained Value } \\
\text { Recommended } \\
\text { Value }\end{array}$ & 2.320 \\
\hline CMIN/DF (Chi-square/Degree of Freedom) & 0.901 & Below 3 \\
\hline GFI (Goodness-of-Fit Index) & Above 0.90 \\
\hline IFI (Incremental Fit Index) & 0.936 & Above 0.90 \\
\hline
\end{tabular}


(Table 5) contd.....

\begin{tabular}{|c|c|c|}
\hline Indices & Obtained Value & Recommended \\
Value
\end{tabular}

Source: Author's Compilation.

\subsection{Structural Model}

Herein, the efforts have been made to test the relationship between emotional indicators on positive psychology. The structural model includes seven constructs: "happiness", "positive emotions", "fear", "sadness", "anger", "disgust", and "positive psychology". In the model, "happiness", "positive emotions", "fear", "sadness", "anger", "disgust" are six independent constructs, and "positive psychology" is a dependent construct. AMOS software was used to test the proposed claims, and recommendations of [45] were followed for assessing the potency of research claims. Fig. (2) reports to a structural relationship between the emotional indicators and positive psychology.

Further, Table 5 summarizes the results of hypothesis testing. The outputs mentioned in the related Table $\mathbf{6}$ offer support for the acceptance of five claims. Besides, results unsupported one proposed claim. More in detail, H1, which reported that happiness positively impacts positive psychology, was strongly supported $(\beta=0.082$, C.R. $=2.050$, and $\mathrm{p}=$ $0.040)$. The $\mathrm{H} 2$, which claimed that the positive emotion positively impacts positive psychology, was supported $(\beta=$ 0.081, C.R. $=2.050$, and $p=0.044)$. Likewise, the H3, which stated that sadness negatively impacts positive psychology, was also confirmed $(\beta=-0.154,-3.845$, and $p=0.000)$. Further, results unsupported the $\mathrm{H} 4$, which claimed that anger positively impacts positive psychology $(\beta=0.029$, C.R. $=$ 0.630 , and $\mathrm{p}=0.529)$. The $\mathrm{H} 5$, which stressed that disgust negatively impacts positive psychology, was supported $(\beta=$ -0.022 , C.R. $=-5.847$, and $\mathrm{p}=0.000$ ). Lastly, H6 which emphasized that fear negatively impacts positive psychology, was also supported $(\beta=-0.128, C . R .=-3.145$, and $p=0.002)$.

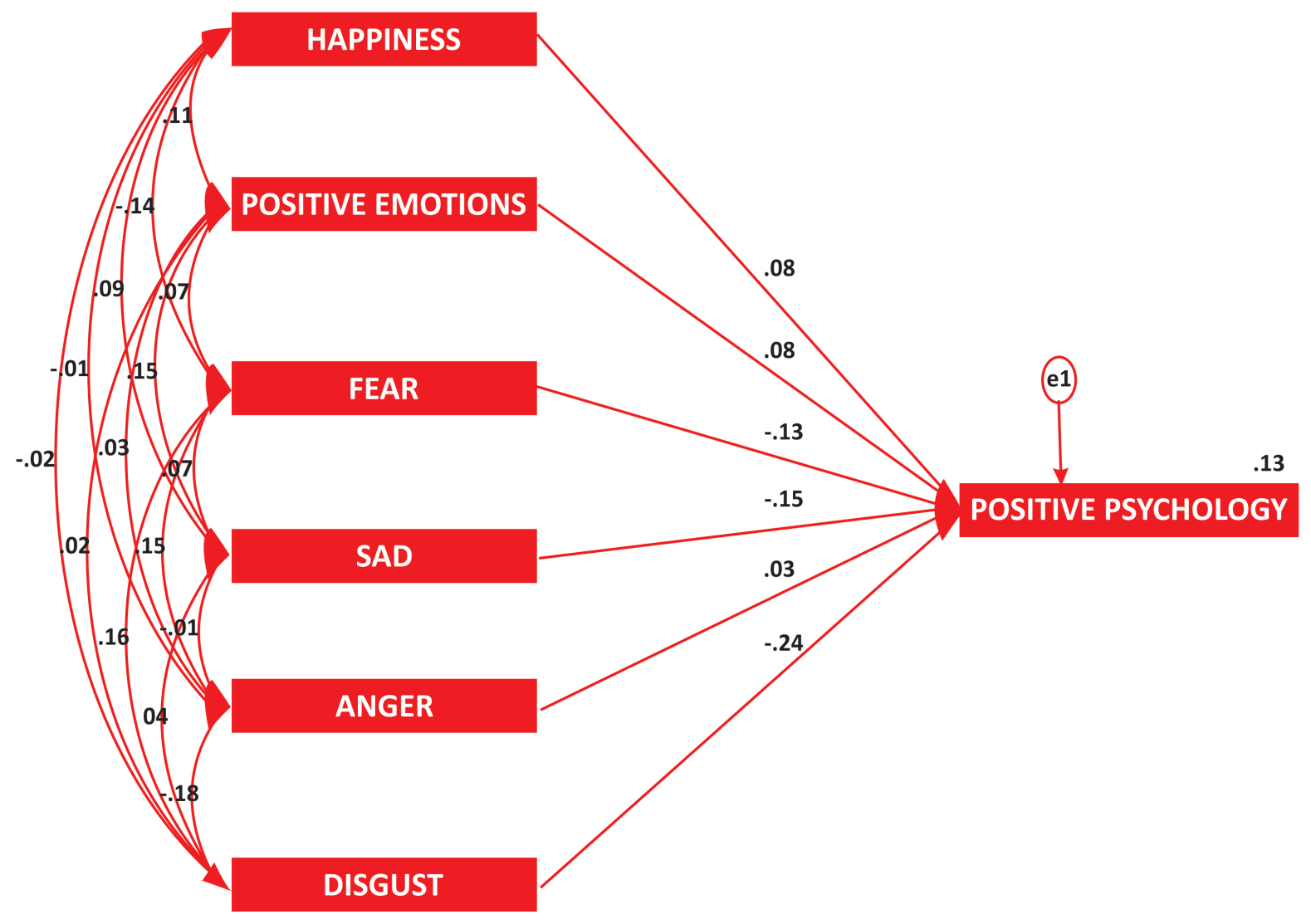

Fig. (2). Structural relationships between the emotional indicators and positive psychology.

Table 6. Results of Hypotheses Testing.

\begin{tabular}{|c|c|c|c|c|c|}
\hline & Hypothesis & $\begin{array}{c}\text { Estimates } \\
(\boldsymbol{\beta})\end{array}$ & C.R. & Sig. & Remark \\
\hline H1 & Happiness shall positively impact positive psychology & 0.082 & 2.050 & 0.040 & Supported \\
\hline
\end{tabular}


(Table 6) contd.....

\begin{tabular}{|c|c|c|c|c|c|}
\hline & Hypothesis & $\begin{array}{c}\text { Estimates } \\
(\beta)\end{array}$ & C.R. & Sig. & Remark \\
\hline H2 & Positive emotions shall positively impact positive psychology & 0.081 & 2.010 & 0.044 & Supported \\
\hline H3 & Sadness shall negatively impact positive psychology & -0.154 & -3.845 & 0.000 & Supported \\
\hline H4 & Anger shall negatively impact positive psychology & 0.025 & 0.630 & 0.529 & Not Supported \\
\hline H5 & Disgust shall negatively impact positive psychology & -0.022 & -5.847 & 0.000 & Supported \\
\hline H6 & Fear shall negatively impact positive psychology & -0.128 & -3.145 & 0.002 & Supported \\
\hline
\end{tabular}

Source: Author's Compilation.

The highest impact of the sadness has been noticed on positive psychology (-0.154) followed by the impact of fear (-0.128), happiness $(0.082)$, positive emotions $(0.081)$, anger (0.025), and disgust (-0.022) on the positive psychology.

The findings of the present study will add to the literature primarily in the Indian context. The previous empirical result has shown that there has been a lot of research on wellbeing in the Indian context [55]. However, very few studies have examined the effect of student's emotions on their positive psychology [56]. The findings of the survey will help educators to understand the importance of student's emotions, and accordingly, different interventions should be given to students depending upon their emotional state. Further, the findings of the current research cannot be compared with the previous studies on positive psychology, which has been mainly conducted in the western context. India is a developing country, and a major chunk of the population in India lives in poverty. Hence, understanding the emotional state of the students becomes more crucial in India as compared to other parts of the world. The Indian students come from a very different cultural background and belong to a unique educational system where many of the resources that are taken for granted in the western world are seen as a luxury in India [57 - 59].

\section{CONCLUSION}

This paper aims to identify the dimensions of emotional indicators and how these dimensions affect positive psychology. The study findings significantly contribute to building a holistic understanding related to emotional indicators. The results of the EFA classified the scale items into six factors as the dimensions of emotional indicators, namely "anger", "disgust", "happiness", "positive emotions", "sadness", and "fear". Further, extracted factors were validated using the CFA approach. As a next step, the CFA model was evaluated for convergent validity, discriminant validity, and model fit. The results confirmed that the CFA model reached the minimum required value of convergent validity and discriminant validity. The results further confirm "anger", "disgust", "happiness", "positive emotions",

The findings conclude that respondents prefer to be too joyful as joy is not followed by sadness, and lots of joy and fun will not cause bad things to happen or bad consequences. Whenever respondents are more cheerful and happy, they can expect bad things that may occur in their life. Meanwhile, they believe that disasters often follow good fortune. Besides, respondents did not consider themselves sadness as compared to their peers. However, experience makes them feel sad. Even small things and situations cannot easily make them sadness as well as they are aware of how to tackle the people/situations that make them feel sad. Further, the respondents believe that they are not well versed in making arguments and will not hit anyone even if they are being provoked. Even in the situation of rage, respondents don't break things. Respondents have not threatened people in their network. Likewise, respondents are amazed when people are nice to them. The study findings further claim that the majority of respondents feel disgusted when they see someone accidentally stick a fishing hook through his/her finger. The positive emotions may lead the students to live their life happily and to reduce the "sadness", and "fear". In such a way, the outcomes considerably contribute to expanding state of the art about emotional indicators of students. As the implications of the results are concerned, it will assist parents, educational institutions, and policymakers in evaluating the emotional perspectives of students, which can help in building a healthy learning environment for the students. The management-bodies of schools should also attempt to create a positive environment within the school, which may include facilities in creating positive emotions [60 - 62].

Although this study provides novel insights to the state-ofart and advances the pertinent literature, nevertheless, it suffers from two limitations. Firstly, the survey respondents were selected from three cities. Therefore, further study can be carried out on a large scale by increasing the number of cities and survey respondents. Secondly, this study explores the aspects of students. Thus, it would be fruitful to include the respondents from other backgrounds to increase the generalization of research findings.

\section{ETHICS APPROVAL AND CONSENT TO PARTI- CIPATE}

Not applicable.

\section{HUMAN AND ANIMAL RIGHTS}

Not applicable.

\section{CONSENT FOR PUBLICATION}

Not applicable.

\section{AVAILABILITY OF DATA AND MATERIALS}

The data that support the findings of this study are available from the corresponding author (A.A) upon reasonable request.

\section{FUNDING}

None. 


\section{CONFLICT OF INTEREST}

The authors declare no conflict of interest, financial or otherwise.

\section{ACKNOWLEDGEMENTS}

Declared none.

\section{REFERENCES}

[1] Sylwester R. How emotions affect learning. Educ Leadersh 1994; 52(2): 60-5.

[2] Jiang $\mathrm{D}, \mathrm{Wu} \mathrm{K}$, Chen $\mathrm{D}$, et al. A probability and integrated learning based classification algorithm for high-level human emotion recognition problems. Measurement 2020; 150107049 [http://dx.doi.org/10.1016/j.measurement.2019.107049]

[3] Oatley K, Keltner D, Jenkins JM. Understanding emotions. Blackwell publishing 2006

[4] Bagozzi RP, Pieters R. Goal-directed emotions. Cogn Emotion 1998; 12(1): $1-26$. [http://dx.doi.org/10.1080/026999398379754]

[5] Briñol P, Petty RE, Rucker DD. The role of meta-cognitive processes in emotional intelligence. Psicothema 2006; 18(Suppl.): 26-33. [PMID: 17295954]

[6] Phan HP, Ngu BH, Lin RY, Wang HW, Shih JH, Shi SY. Predicting and enhancing students' positive emotions: An empirical study from a Taiwanese sociocultural context. Heliyon 2019; 5(10)e 02550 [http://dx.doi.org/10.1016/j.heliyon.2019.e02550] [PMID: 31667399]

[7] Lopez RB, Denny BT. Negative affect mediates the relationship between use of emotion regulation strategies and general health in college-aged students. Pers Individ Dif 2019; 151109529 [http://dx.doi.org/10.1016/j.paid.2019.109529]

[8] Hunter KH, Devine K. Doctoral students' emotional exhaustion and intentions to leave academia. Int J Dr Stud 2016; 11(2): 35-61.

[9] Abuse S. Mental Health Services Administration Key substance use and mental health indicators in the United States: Results from the 2016 National Survey on Drug Use and Health (HHS Publication No SMA 17-5044, NSDUH Series H-52). Rockville, MD: Center for Behavioral Health Statistics and Quality. Substance Abuse and Mental Health Services Administration 2017.

[10] Zisook S, Lesser I, Stewart JW, et al. Effect of age at onset on the course of major depressive disorder. Am J Psychiatry 2007; 164(10): $1539-46$.

[http://dx.doi.org/10.1176/appi.ajp.2007.06101757]

[PMID: 17898345]

[11] Trigwell K, Ellis RA, Han F. Relations between students' approaches to learning, experienced emotions and outcomes of learning. Stud High Educ 2012; 37(7): 811-24.

[http://dx.doi.org/10.1080/03075079.2010.549220]

[12] Derick L, Sedrakyan G, Munoz-Merino PJ, Kloos CD, Verbert K. Evaluating emotion visualizations using AffectVis, an affect-aware dashboard for students. J Res Innovative Teach Learning 2017. [http://dx.doi.org/10.1108/JRIT-05-2017-0011]

[13] Värlander S. The role of students' emotions in formal feedback situations. Teach High Educ 2008; 13(2): 145-56. [http://dx.doi.org/10.1080/13562510801923195]

[14] Pekrun R. The control-value theory of achievement emotions: Assumptions, corollaries, and implications for educational research and practice. Educ Psychol Rev 2006; 18(4): 315-41.

[http://dx.doi.org/10.1007/s10648-006-9029-9]

[15] Park JJ, Freeman JL, Schallert DL, Steinhardt MM. How emotions contribute to graduate students' psychological responses during their online application for human subject research approval. Studies in Graduate and Postdoctoral Education 2017; 8(2): 169-88.

[http://dx.doi.org/10.1108/SGPE-D-17-00015]

[16] Ciarrochi J, Atkins PW, Hayes LL, Sahdra BK, Parker P. Contextual positive psychology: Policy recommendations for implementing positive psychology into schools. Front Psychol 2016; 7: 1561. [http://dx.doi.org/10.3389/fpsyg.2016.01561] [PMID: 27777564]

[17] Kashdan TB, Ciarrochi J, Eds. Mindfulness, Acceptance, and Positive Psychology: The Seven Foundations of Well-being. Oakland, CA: Context Press 2013.

[18] Parks A, Biswas-Diener R. "Positive interventions: past, present, and future," in Mindfulness, Acceptance, and Positive Psychology: The Seven Foundations of Well-being. Oakland, CA: New Harbinger 2013.
[19] Dhaliwal MS, Mittal A, Aggarwal A, Chand PK. Determining the factors affecting the selection of private universities and colleges in indian context: A structural equation modeling approach. J Adv Res Dynamical \& Control Sys 2019; 11(8): 2579-90.

[20] Chand PK, Kumar AS, Mittal A. Emotional intelligence and its relationship to employability skills and employer satisfaction with fresh engineering graduates. Int J Qual Res 2019; 13(3)

[21] Sutter-Brandenberger CC, Hagenauer G, Hascher T. Students' selfdetermined motivation and negative emotions in mathematics in lower secondary education-Investigating reciprocal relations. Contemp Educ Psychol 2018; 55: 166-75

[http://dx.doi.org/10.1016/j.cedpsych.2018.10.002]

[22] Welpe IM, Spörrle M, Grichnik D, Michl T, Audretsch DB. Emotions and opportunities: The interplay of opportunity evaluation, fear, joy, and anger as antecedent of entrepreneurial exploitation. Entrep Theory Pract 2012; 36(1): 69-96.

[http://dx.doi.org/10.1111/j.1540-6520.2011.00481.x]

[23] Pekrun R, Frenzel AC, Goetz T, Perry RP. The control-value theory of achievement emotions: An integrative approach to emotions in education.Emotion in education. Academic Press 2007; pp. 13-36. [http://dx.doi.org/10.1016/B978-012372545-5/50003-4]

[24] Morrison AS, Heimberg RG. Social anxiety and social anxiety disorder. Annu Rev Clin Psychol 2013; 9: 249-74.

[http://dx.doi.org/10.1146/annurev-clinpsy-050212-185631] [PMID: 23537485]

[25] Stein A, Malmberg LE, Sylva K, Barnes J, Leach P. FCCC team. The influence of maternal depression, caregiving, and socioeconomic status in the post-natal year on children's language development. Child Care Health Dev 2008; 34(5): 603-12.

[http://dx.doi.org/10.1111/j.1365-2214.2008.00837.x] [PMID: 18549438]

[26] Lackéus M. Emotions in entrepreneurial education: A literature review. Proceedings of Institute of Small Business and Entrepreneurship (ISBE) Conference.

[27] Daniels LM, Gierl MJ. The impact of immediate test score reporting on university students' achievement emotions in the context of computer-based multiple-choice exams. Learn Instr 2017; 52: 27-35. [http://dx.doi.org/10.1016/j.learninstruc.2017.04.001]

[28] Immordino-Yang MH, Damasio A. We feel, therefore we learn: The relevance of affective and social neuroscience to education. Mind Brain Educ 2007; 1(1): 3-10. [http://dx.doi.org/10.1111/j.1751-228X.2007.00004.x]

29] Baker RS, D'Mello SK, Rodrigo MM, Graesser AC. Better to be frustrated than bored: The incidence, persistence, and impact of learners' cognitive-affective states during interactions with three different computer-based learning environments. Int J Hum Comput Stud 2010; 68(4): 223-41.

[http://dx.doi.org/10.1016/j.ijhcs.2009.12.003]

[30] Taub M, Azevedo R, Rajendran R, Cloude EB, Biswas G, Price MJ. How are students' emotions related to the accuracy of cognitive and metacognitive processes during learning with an intelligent tutoring system? Learn Instr 2019.101200

[http://dx.doi.org/10.1016/j.learninstruc.2019.04.001]

[31] D'Mello S, Graesser A. Dynamics of affective states during complex learning. Learn Instr 2012; 22(2): 145-57.

[http://dx.doi.org/10.1016/j.learninstruc.2011.10.001]

[32] Werner-Seidler A, Banks R, Dunn BD, Moulds ML. An investigation of the relationship between positive affect regulation and depression. Behav Res Ther 2013; 51(1): 46-56.

[http://dx.doi.org/10.1016/j.brat.2012.11.001] [PMID: 23178678]

[33] Zembylas M. Teaching and teacher emotions: A post-structura perspective.New understandings of teacher's work. Dordrecht: Springer 2011; pp. 31-43.

[http://dx.doi.org/10.1007/978-94-007-0545-6 3]

[34] Mainhard T, Oudman S, Hornstra L, Bosker RJ, Goetz T. Student emotions in class: The relative importance of teachers and their interpersonal relations with students. Learn Instr 2018; 53: 109-19. [http://dx.doi.org/10.1016/j.learninstruc.2017.07.011]

[35] Appleton AA, Buka SL, Loucks EB, Gilman SE, Kubzansky LD Divergent associations of adaptive and maladaptive emotion regulation strategies with inflammation. Health Psychol 2013; 32(7): 748-56. [http://dx.doi.org/10.1037/a0030068] [PMID: 23815767]

[36] Appleton AA, Loucks EB, Buka SL, Kubzansky LD. Divergent associations of antecedent- and response-focused emotion regulation strategies with midlife cardiovascular disease risk. Ann Behav Med 2014; 48(2): 246-55

[http://dx.doi.org/10.1007/s12160-014-9600-4] [PMID: 24570218] 
[37] Peterson ER, Brown GT, Jun MC. Achievement emotions in higher education: A diary study exploring emotions across an assessment event. Contemp Educ Psychol 2015; 42: 82-96.

[http://dx.doi.org/10.1016/j.cedpsych.2015.05.002]

[38] Pekrun R, Goetz T, Titz W, Perry RP. Academic emotions in students' self-regulated learning and achievement: A program of qualitative and quantitative research. Educ Psychol 2002; 37(2): 91-105.

[http://dx.doi.org/10.1207/S15326985EP3702_4]

[39] Pekrun R, Goetz T, Frenzel AC, Barchfeld P, Perry RP. Measuring emotions in students' learning and performance: The Achievement Emotions Questionnaire (AEQ). Contemp Educ Psychol 2011; 36(1): 36-48.

[http://dx.doi.org/10.1016/j.cedpsych.2010.10.002]

[40] Spangler G, Pekrun R, Kramer K, Hofmann H. Students' emotions, physiological reactions, and coping in academic exams. Anxiety Stress Coping 2002; 15(4): 413-32.

[http://dx.doi.org/10.1080/1061580021000056555]

[41] Linnenbrink EA, Pintrich PR. Achievement goal theory and affect: An asymmetrical bidirectional model. Educ Psychol 2002; 37(2): 69-78. [http://dx.doi.org/10.1207/S15326985EP3702_2]

[42] Linnenbrink-Garcia L, Pekrun R. Students' emotions and academic engagement: Introduction to the special issue. Contemp Educ Psychol 2011; 36(1): 1-3.

[http://dx.doi.org/10.1016/j.cedpsych.2010.11.004]

[43] Cardon MS, Foo MD, Shepherd D, Wiklund J. Exploring the heart: Entrepreneurial emotion is a hot topic. Entrep Theory Pract 2012; 36(1): 1-0.

[http://dx.doi.org/10.1111/j.1540-6520.2011.00501.x]

[44] Wharton AS. The sociology of emotional labor. Annu Rev Sociol 2009; 35: 147-65.

[http://dx.doi.org/10.1146/annurev-soc-070308-115944]

[45] Hair J, Black W, Babin B, Anderson R, Tatham R. Upper Sadnessdle River, NJ: Prentice Hall, Multivariate Data Analysis. 7th edn. 2010.

[46] Comrey AL, Lee HB. A First Course in Factor AnalysisHillsdale, NJ: L. 2nd Edn.

[http://dx.doi.org/10.4324/9781315827506]

[47] Fornell C, Larcker DF. Evaluating structural equation models with unobservable variables and measurement error. J Mark Res 1981; 18(1): 39-50.

[http://dx.doi.org/10.1177/002224378101800104]

[48] Aggarwal A, Dhaliwal RS, Nobi K. Impact of structural empowerment on organizational commitment: the mediating role of women's psychological empowerment. Vision (Basel) 2018; 22(3): 284-94. [http://dx.doi.org/10.1177/0972262918786049]

[49] Kaiser HF. A second generation little jiffy. Psychometrika 1970; 35 : 401-15.

[http://dx.doi.org/10.1007/BF02291817]

[50] Manohar S, Mittal A, Marwah S. Service innovation, corporate reputation and word-of-mouth in the banking sector. Benchmarking (Bradf) 2019; 27(1): 406-29.

[http://dx.doi.org/10.1108/BIJ-05-2019-0217]

[51] Uppal V, Mittal A. Antecedents of post purchase consumer dissatisfaction in household white goods. J Adv Res Dynamical \& Control Systems 2019; 11(5): 1958-66.

[52] Aggarwal A, Mittal R, Gupta S, Mittal A. Internet of things driven perceived value co-creation in smart cities of the future: A pls-sem based predictive model. J Comput Theor Nanosci 2019; 16(9): 4053-8. [http://dx.doi.org/10.1166/jctn.2019.8292]

[53] Aggarwal A, Goyal J, Nobi K. Examining the impact of leadermember exchange on perceptions of organizational justice: The mediating role of perceptions of organizational politics. Theor Econ Lett 2018; 8(11): 2308-29.

[http://dx.doi.org/10.4236/tel.2018.811150]

[54] Aggarwal A, Chand PK, Jhamb D, Mittal A. Leader-Member exchange, work engagement, and psychological withdrawal behavior: The mediating role of psychological empowerment. Front Psychol 2020; 11: 423.

[http://dx.doi.org/10.3389/fpsyg.2020.00423] [PMID: 32296361]

[55] Ghosh A, Deb A. Positive psychology progress in India: Accomplishments and pathways ahead. Psychol Stud (Mysore) 2016; 61(3): 113-25.

[http://dx.doi.org/10.1007/s12646-016-0367-5]

[56] Fredrickson BL. The value of positive emotions: The emerging science of positive psychology is coming to understand why it's good to feel good. Am Sci 2003; 91(4): 330-5.

[http://dx.doi.org/10.1511/2003.4.330]

[57] Goyal J, Kaur H, Aggarwal A. Investigating the technical and scale efficiencies of indian textile industry: A target setting based analysis through DEA. IUP J Operations Manage 2017; 16(1): 16-38.

[58] Mittal A, Aggarwal A, Mittal R. Predicting University Students' adoption of Mobile News Applications.International Journal of EServices and Mobile Applications . 2020.

[59] Jhamb D, Aggarwal A, Mittal A, Paul J. Experience and attitude towards luxury brands consumption in an emerging market. European Business Review 2020.

[60] Aggarwal A, Mittal A, Rasheed MA. Thematic analysis of employee competencies in an uncertain business environment: A study on the indian infrastructure sector. J Adv Res Dynamical Control Syst 2019; 11(8): 1289-301.

[61] Singh J, Chand P, Mittal A, Aggarwal A. High-performance work system and organizational citizenship behaviour at the shop floor. Benchmarking (Bradf) 2020; 27(4): 1369-98.

[http://dx.doi.org/10.1108/BIJ-07-2019-0339]

[62] Kaur P, Mittal A. Meaningfulness of work and employee engagement: The role of affective commitment. Open Psychol J 2020; 13(1): 115-22.

[http://dx.doi.org/10.2174/1874350102013010115]

\section{(C) 2020 Grover et al.}

This is an open access article distributed under the terms of the Creative Commons Attribution 4.0 International Public License (CC-BY 4.0), a copy of which is available at: (https://creativecommons.org/licenses/by/4.0/legalcode). This license permits unrestricted use, distribution, and reproduction in any medium, provided the original author and source are credited. 